\title{
Child domestic work and transitions to commercial sexual exploitation: Evidence from Ethiopia
}

Annabel Erulkar

Population Council

Follow this and additional works at: https://knowledgecommons.popcouncil.org/departments_sbsr-pgy

Part of the Demography, Population, and Ecology Commons, Family, Life Course, and Society Commons, International Public Health Commons, and the Maternal and Child Health Commons How does access to this work benefit you? Let us know!

\section{Recommended Citation}

Erulkar, Annabel. 2018. "Child domestic work and transitions to commercial sexual exploitation: Evidence from Ethiopia," brief. Addis Ababa: Population Council. 


\section{CHILD DOMESTIC WORK AND TRANSITIONS TO COMMERCIAL SEXUAL EXPLOITATION: EVIDENCE FROM ETHIOPIA}

\section{INTRODUCTION}

Child domestic work is one of the most common forms of child labor globally and is considered a form of modern-day slavery (UNICEF 1999; Black 2002). There are an estimated 17.2 million child domestic workers in the world, and the vast majority are girls (ILO 2012). Domestic work keeps children out of school, confined to the home, socially isolated, and burdened with excessive domestic duties (Black 2002). Their time and movements are strictly controlled by their employers. Younger domestic workers are often preferred by employers as they are easier to control and manipulate, and they demand little or no pay (HRW 2006).

Domestic work is one of the most common forms of paid work among girls in Ethiopia. In one study of nearly 10,000 young people in six regions, 37 percent of working urban girls were engaged in domestic work (Erulkar et al. 2010). Domestic work is characterized by extremely low pay or no pay at all, and the working hours and work burdens make the profession exploitive in many cases. A significant number of former domestic workers report being sexually abused in the context of work, and emerging studies indicate that domestic workers are at higher risk of nonconsensual sex compared to their counterparts who are not engaged in domestic work (Erulkar and Ferede 2009). This is compounded by the fact that domestic work is not regulated by labor laws in Ethiopia. Evidence is emerging that domestic work is a feeder profession for sex work. One study of more than 2,000 commercial sex workers in five Ethiopian towns found that 42 percent were former domestic workers, partly supporting the hypothesis that domestic work is a feeder profession to sex work (Girma and Erulkar 2009). However, little is known about transitions to commercial sex work (among young women aged 18 and over) or commercial sexual exploitation (among minors under age 18) in Ethiopia.

\section{METHODS}

In 2015-16, the Population Council undertook a study of migrant, out-of-school girls in Ethiopia (Erulkar, Medhin, and Negeri 2017). The study took place in urban and rural areas in six Ethiopian regions and included both qualitative and quantitative data collection. In the qualitative study, 143 respondents were interviewed in depth, including 47 girls who were currently in domestic work. The

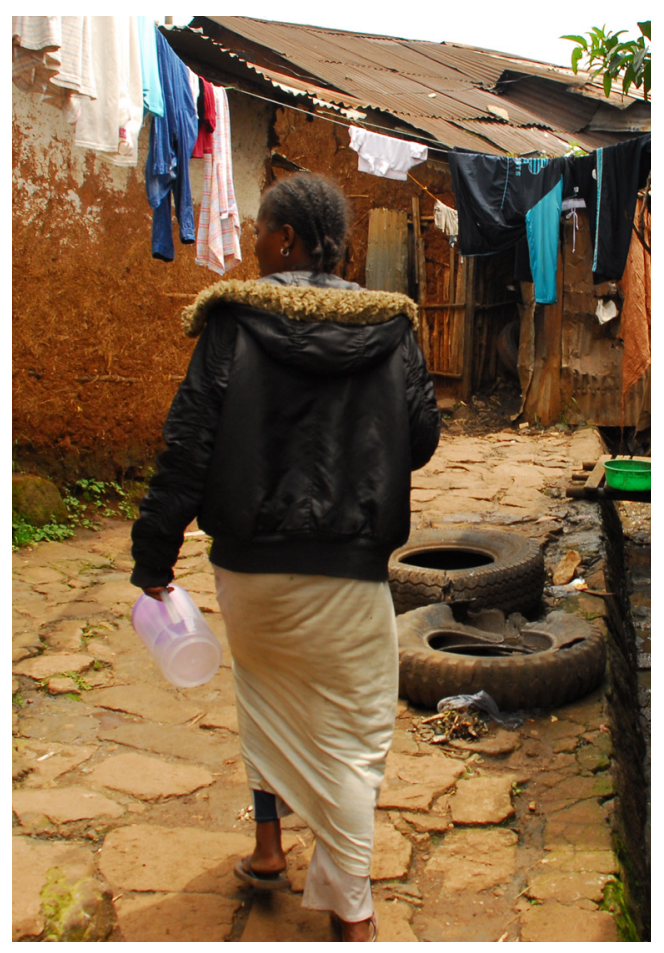

Photo credit: Zeleman Productions

The Population Council conducts research and delivers solutions that improve lives around the world. Big ideas supported by evidence:

It's our model for global change. popcouncil.org

(c) 2018 The Population Council, Inc.

NoVo Foundation

create. change.
POPULATION COUNCIL

Ideas. Evidence. Impact. 


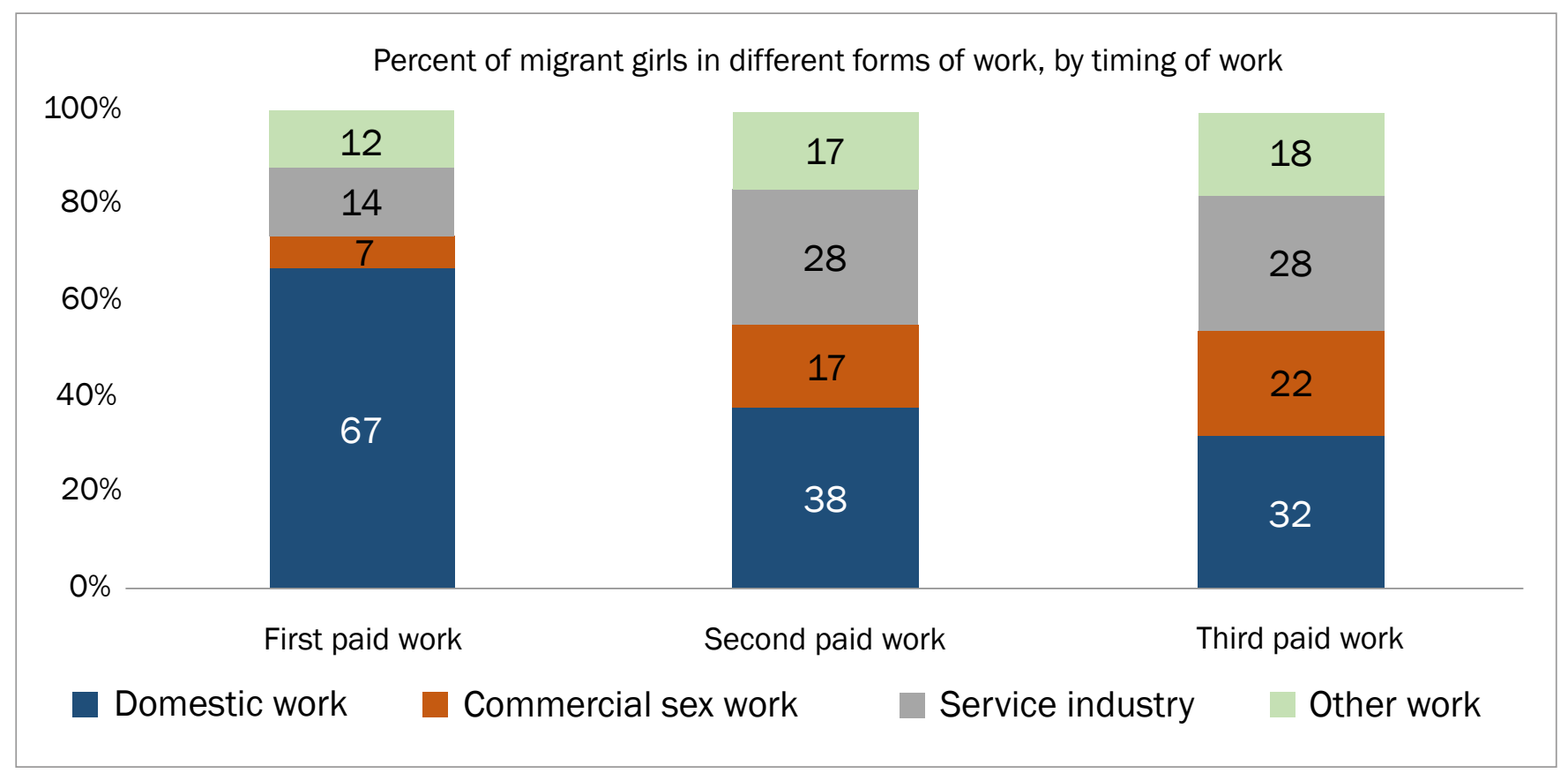

subsequent quantitative survey included interviews with 4,540 urban migrants aged 15 to 24 and 732 rural girls. Among the urban migrants, 796 (18 percent of respondents) were commercial sex workers aged 18 or older at the time of the survey. Interviews covered a range of topics, including family and educational background, social networks, and migration and livelihoods history.

\section{RESULTS}

Domestic work is frequently the initial survival strategy for rural Ethiopian girls migrating to urban areas.

Following migration from rural areas, most girls enter the workforce as domestic workers (67 percent) (Figure 1). However, the second and third jobs after migration are more diverse, and increasing numbers of migrant girls enter commercial sex work: 7 percent in the first job, 17 percent in the second job, and 22 percent in the third job.

Among girls who described themselves as commercial sex workers, nearly half (49 percent) started before the age of 18 , while 51 percent started at age 18 or older. Underage sex work is commercial sexual exploitation and considered a form of human trafficking (USAID 2012). Among girls who started sex work younger than age 18, 44 percent had their first sexual experience in the context of the work, compared to 22 percent of girls who started such work at age 18 or older, a difference that is statistically significant.
Nearly half of the commercial sex workers in the sample (49 percent) were formerly domestic workers. Forty-one percent of commercial sex workers reported that they entered sex work to escape other abusive forms of work such as domestic work.

It is generally the hard domestic work and the abuse that led me into sex work... I was just fed up with domestic work and I was angry most of the time. I finally decided to start working in this business.

-Commercial sex worker in Adama, age 20, migrated at age 15,5 years of education

About one in five girls involved in sex work started as a result of deception or trickery by an employer or broker (21 percent of girls who started under age 18, and 17 percent of girls who started at age 18 and over), which is a form of trafficking. A number of girls described conditions of coercion and trafficking that led them into sex work.

It was the owner of the hotel in Aksum who took me. He said that I am going to work as a waitress.... He said, "We will go to such-and-such a place. You can return after two days if you don't like it." He made it seem like the place was not very far and I assumed that the place is only somewhere around Dessie.... [On the travel day] I held only a bag [of belongings] but he told me to leave them home. He said that he is going to buy things for me. It was the owner of the hotel who threatened me. He increased my debt. 
Even if you have money, he doesn't give it to you in case you want to leave.... I found [co-workers] changing their clothes and grooming themselves. I was amazed at this and I asked to understand the work. They said to me, "He is going to ask you for something..." and then I asked them what it is. They answered, "Ooh, don't you know?" -Commercial sex worker, Mekelle, age 20, migrated at age 15, 5 years of education

\section{RECOMMENDATIONS}

The study demonstrated that domestic work is frequently a feeder profession for commercial sexual exploitation/ commercial sex work. Originating from poor rural areas and armed with little in the way of education, domestic workers receive low pay and frequently work in abusive situations. The domestic work conditions described create unbearable conditions for girls and they enter into commercial sex work as an alternative, hoping for an improvement in their work situation. The study also found that a considerable number of girls are trafficked into sex work, through deception by employers and brokers. Several programmatic recommendations arise from this study:

\section{Programs to address exploitation and abuse of} domestic workers

Significant numbers of the most marginalized girls enter domestic work and many report sexual abuse. In Ethiopia, domestic workers are not regulated by the labor law and the country has not ratified ILO's Domestic Workers Convention (C189), which calls for standards and protections for domestic workers. Programs should raise awareness of the rights of domestic workers and actively promote provisions in the convention.

\section{Increased attention to trafficking (not just across} international borders)

Much attention has been focused in Ethiopia on the international "maid trade" and cross-border migration, smuggling, and trafficking (UNICEF 2017). Our research suggests that a considerable number of girls within Ethiopia are victims of deception, coercion, and trafficking. Nearly 20 percent of sex workers described the deception of brokers and employers at the time of entry into sex work, including transporting rural girls great distances to join the trade. Little attention has been paid to internal trafficking, and increased programmatic action to address trafficking, including the role of brokers, is warranted.

\section{REFERENCES}

Black, M. 2002. "Child Domestic Workers: Finding a Voice." London: Anti-Slavery International.

Erulkar A. and A. Ferede. 2009. "Social exclusion and early, unwanted sexual initiation in poor urban settings in Ethiopia," International Perspectives on Sexual and Reproductive Health 35(4): 186-193.

Erulkar, A., A. Ferede, W. Ambelu, et al. 2010. "Ethiopia Young Adult Survey: A Study in Seven Regions." Addis Ababa: Population Council and UNFPA. September.

Erulkar, A., G. Medhin, and L. Negeri. 2017. "The Journey of Out-of-School Girls in Ethiopia: Examining Migration, Livelihoods, and HIV." Addis Ababa: Population Council. August.

Girma, W. and A. Erulkar. 2009. “Commercial Sex Workers in Five Ethiopian Cities: A Baseline Survey for Targeted HIV Prevention for Most-at-Risk Populations." Report. Addis Ababa: Population Council. September.

Human Rights Watch (HRW). 2006. "Swept under the rug: Abuses against domestic workers around the world," Human Rights Watch 18(7).

International Labour Organization (ILO). 2012. “Child Domestic Work: Global Estimates 2012." Geneva: ILO International Programme on the Elimination of Child Labour (IPEC).

UNICEF. 1999. "Child domestic work," Innocenti Digest. Florence, Italy: UNICEF.

----. 2017. "A Child Is a Child: Protecting Children on the Move from Violence, Abuse and Exploitation." New York: UNICEF. May.

USAID. 2012. "Counter-Trafficking in Persons Policy." Washington, DC: USAID. February.

This study is made possible by the generous support of the American people through the United States Agency for International Development-President's Emergency Plan for AIDS Relief (USAID-PEPFAR) and the Oak and Novo Foundations. The contents are the responsibility of the authors and do not necessarily reflect the views of USAID or the United States Government, or the Oak or Novo Foundations. 
